\title{
COMIPETITION IN OIL
}

\section{THE GULF COAST REFINERY MARKET, 1925-1950}

By DANIEL C. HAMILTON. The first published exploration of the structure and behavior of the largest, most influential refinery market in the world, this volume also provides the only published analysis of the relation of product prices to crude costs, the time pattern of price and output behavior, the relation of cost behavior to price-output behavior, and the other dimensions of Gulf market performance.

\section{THE NIGER AGRICULTURAL PROJECT} AN EXPERIMENT IN AFRICAN DEVELOPMENT

$B y K$. D. S. BALDWIN. In recent years many heavily capitalized schemes have been started to assist underdeveloped areas. Although wide experience has been utilized many of them have failed to achieve their objectives.

Mr. Baldwin has made a critical socio-economic analysis of the history of a particularly well-documented agricultural project in Nigeria. Here, he discusses the handling of the problems arising in the initial planning stages of the project and the causes of its failure. 200 pages. 4 maps. 8 pages of illustrations. Tables.

$\$ 5.00$

\section{THE EFFICIENCY OF THE COAL INDUSTRY}

\section{AN APPLICATION OF LINRAR PRogramming}

By JAMES M. HENDERSON. Using the years 1947, 1949 and 1951 for norm estimates, this comparative study of estimated-actual efficiency analyzes each of the United States' 22 coal-producing and 14 coal-consuming areas on the basis of production capacity, extraction cost, transport cost, and consumer demand. Mr. Henderson's comparative assessments indicate an efficiency level directly related to total demand, but do not rule out the influences of union activity and the structure of the industry itself.

$\$ 4.50$

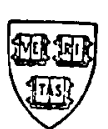

Through your bookseller, or from

\section{HARVARD UNIVERSITY PRESS}

79 Garden Street, Cambridge 38, Massachusetts

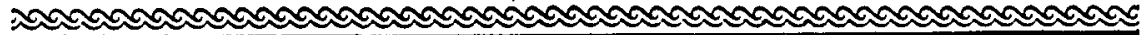




\section{LABOR PROBLEMS IN THE INIDUSTRIAL DEVELOPMENT OF INDAA}

By CHARLES ANDREW MYERS. What problems arise when an underdeveloped country with traditions of political liberty undertakes planned industrialization? This widely applicable study of India's five-year plans discusses the history of industrial development, and analyzes the problems arising from overpopulation and resultant low wage levels, the beginnings of labor organization and its management counterpart, and, finally, the role of government in a situation of labor protests versus planned economic goals.

$\$ 6.50$

\section{TRADE UNION LEADERSHIP}

By VICTOR L. ALLEN. Based on the life and experiences of the late Arthur Deakin, General Secretary of Britain's Transport and General Workers' Union, this descriptive analysis of the power of a trade union leader is relevant far beyond the limits of a single union or nation. Its material on leadership ethics, union development, problems and administration has universal validity while the story of Mr. Deakin's anti-communist campaign is of particular interest and importance.

$\$ 6.00$

\section{SELECTED PAPERS IN ECONOMIC THEORY}

By KNUT WICKSELL. Edited with an Introduction by ERIK LINDAHL. This book makes available to the English reader some of the most important and interesting papers by Knut Wicksell. His main theories—on the value of money, marginal productivity, the nature of capital, etc.-are presented in a very readable form, while an introductory essay by Erik Lindahl tells the story of his life and gives some insight into his forceful personality.

$\$ 6.50$

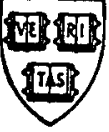

Through your bookseller, or from

\section{HARVARD UNIVERSITY PRESS}

79 Garden Street, Cambridge 38, Massachusetts

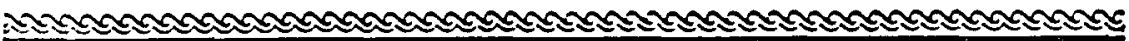

Please mention THE JOURNAL when answering advertisements 


\section{PUBLICATIONS}

The principles of economics applied to the formation and evaluation of economic policies, and a new collection of outside readings by leading contemporary economists . . .

PRINCIPLES OF ECONOMIC POLICY

by KENNETH E. BOULDING, University of Michigan

A basic text for any course dealing with economic policy. Requires no prerequisites. The purpose of the book is to develop first, the principles and then to relate these principles to basic areas of economic policy. The first part of the book discusses four basic objectives of economic policy: progress, stability, justice and freedom. The second part discusses the extent to which these four objectives may be achieved in a number of different policy areas.

Outstanding Features: 1 . Directed at principles, not at techniques. This is a book of "ideas"; it is not a compilation of actual information. Factual material is used only to illustrate "principles." 2. The student is encouraged to form a view of Economic policy as a whole, rather than in piecemeal units. 3 . The final chapter ties the work together with ethics. To quote the author, "At the policy level economics without ethics is a lever without a fulcrum." 4. There are no problems. Contents include: Economic Progress; Economic Stability; Economic Justice; Economic Freedom; Principles of Action Applied to Government; Income Maintenance Policy; Government and Business Enterprise; The Economics of War and Peace; The World Perspective: Communism and Development.

440 pp. Pub. 1958 Text price $\$ 5.95$

\section{SELECTED READINGS IN ECONOMICS}

\author{
by C. LOWELL HARRISS,
} Columbia University

Presents distinguished, complementary outside readings to go with any basic text and provide a complete work which makes reference to libraries and other sources unnecessary. It is especially useful as a supplemental text for all basic courses in Economics, usually called: Introductory Economics, Principles of Economics, Economic Analysis, Intermediate Economics, Economic Theory, Social Sciences, Elementary Business Economics, Contemporary Civilization. Useful also, in elementary courses in Sociology and Political Science.

The purposes behind the selections are to introduce students to the literature of intrinsic merit, written by outstanding economists, to provide readings within the intellectual group of the average beginning student, to complement material in the basic text and to present various points of view to permit flexibility. The readings may be used in any order, and particular sections omitted if desired. Contents include: What Is Economics, The Business System, Costs and Prices, Dealing with Monopoly, Consumption and Consumer Problems. Adequate coverage is given for every important topic, and by many authorities.

546 pp. Pub. 1958 Text price $\$ 3.95$

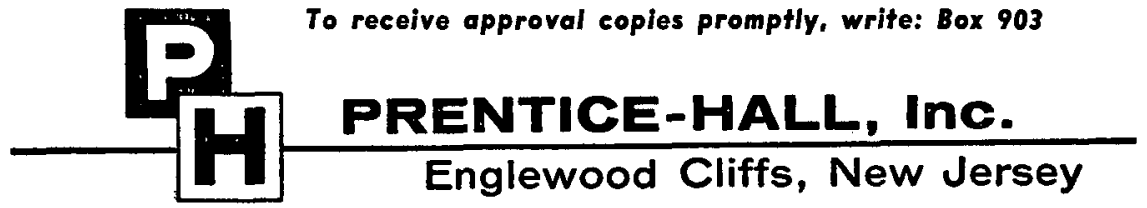

Please mention THE JOURNAL when answering advertisements 